岩石鉱物鉱床学会誌

53 巻 6 号, 1965 年

\title{
青森県七戸地方の山砂鉄鉱床 一砂鉄鉙床の堆皘環境と撓曲構造一
}

On the sedimentary environment and its warping structure of the mountain iron sand placer deposits, Shichinohe district,

Aomori Prefecture (II)

斎 藤 洋 彦 (Hirohiko Saitoh)

\section{3. 砂鉄鉱床の形成過程について}

A. 地翼 年 代

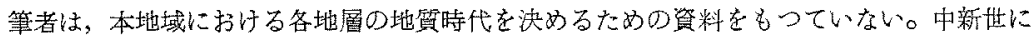

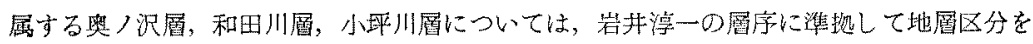
行なつたが，この上位にある甫ノ渡層，清水目層の地質年代については明らかでない。甫

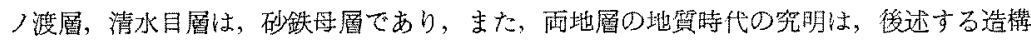
運動の時期にも深い関連があるので，次にこれに関する問題点について述へることにす る。

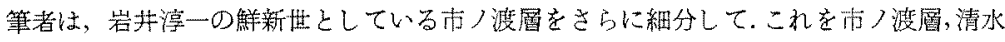
目層抢よび底田秒岩・碩岩部層に細分した。この清水层層を本地域外の東部人追跡する と，柴崎達夫ら（1958）による下北半島南部の甲地層につながるが，北村信 (1963) は この甲地層を，下北半島の砂子叉層と同一地層であると確めているので，清水目層方砂子 及層に対比されることは確実である。一方，本地域の南柬方にある北上山地北端部におるい て，鎮西清高 (1958) は，三戸層群上部の久保，斗川両罢層が，大桑万願寺動物群で特徵 ずけられるので，これらを鮮新統と考えているが，筆者は単に岩質的見地から，一応市， 渡層を久保累層に，清水目層を斗川罢層にそれぞれ対比してみた。

㳄に，化石については，筆者埰集化石と，青木滋（1958）の同定化石とを総合した增 田孝一郎*の見解に上れば，これらの化石は，增田の規定した日本沿呰区動物地理区に属 し，東北襄日本の笹岡層，大彩迦層，蟹田層あたりに対比されるもので，鮮新世初期に属 するという。しかしながら，青木滋の同定した化石は，地域外東方の東北線石文駅附近の 甲地層 (清水目層) 加ら採集したものであつて，市ノ渡層中方らは，未だ現生種化石だ しか発見されていないようであり，市ノ渡首の年代の決め手が得られない現状である。

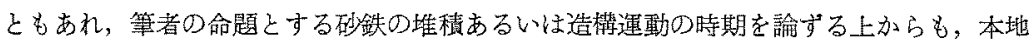
域の地覒年代の決定は，重要な意義をもつているので，今後の古生物学的研究に期待する 次第である。

* 同氏からの秘信による 


\section{B. 堆積作用と造構運動との関連性}

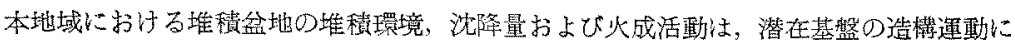

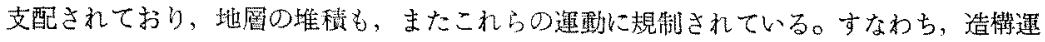

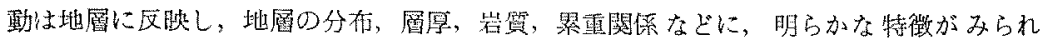

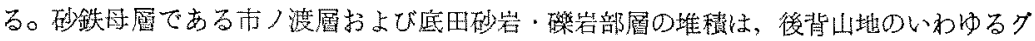

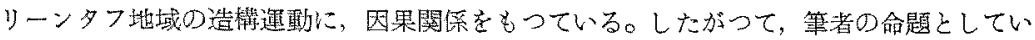

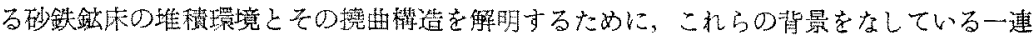

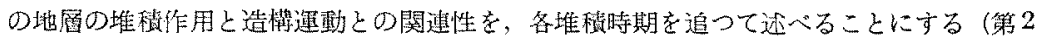
図)。

小坪川層形成期 本地域の堆䅡盆地の発展に最も影響を与えたものは，北西〜南東系の 上田断層である(第 3 因)。本断層を境ししてその西南側が上景し，北東側が沈降したために

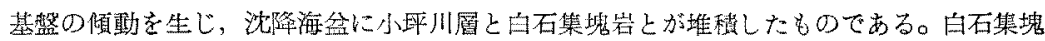
岩は，その最沈降部である大坪川，丞ノ木沢附近を中心として堆程したがこれと同留の集

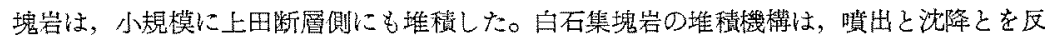

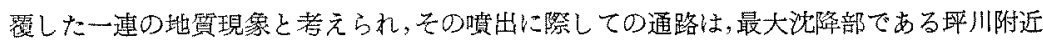
では，上原子断層にみられるような束西系裂かであつたろうし，一方上田断首附近では， 上田断層が值接の通路となつたものであろう。なお，會岡川附近にみられる小評川層中の

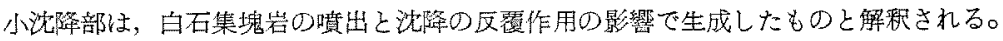

市ノ渡層形成期 地域は，小玶川層うよび白石集塊岩が堆積した後に，一旦陸化し，鮮 新世に入つてから再び沈降がはじまつたが，この沈降の性質は，捘背山地の基整の美別的上 景量動に起因するものである。市ノ渡層は，この運動に規制されて，地区ことに断片的に 堆積し，その層厚も各地区で著しく变化している。この隆起は，北部地域，白石集塊岩， 上田断層南西側山地など，本地域の全面におよんだものであるが，もちろん，これら地区 加一稼に隆起したものではなく，地区每に隆起の度合を異にし，また瀕繁に隆起と沈降と を繰返しながら，地区ことに凸凹の隆起部と沈降部を形成していつたものであるう。この 際，小坪川形成期に沈降部の中心部にあつた栗ノ末沢附近は，白石集塊岩の隆起にともな い，䎐化して隆起の中心になつたが，一方で沈降の中心註，白石集塊岩および上田断層南 西部の隆起に規制され，倉岡川附近に移動した。また，隆起速度も地区毎に異なつていた

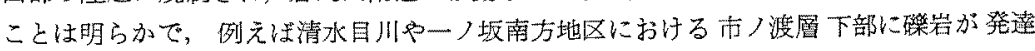
し，まれに径 $1 \mathrm{~m} に$ によぶ巨磁さえみられる事実は，後背山地が，局地的に激しく隆起 したことを物語つている。なお，上田断層の傾動沈降運動は，先小坪川層形成期からはし まり，小玶川層形成期全期間をとおして活動したが，市ノ渡層形成期前に，その活動は全 くやんでいた。このことは，本断層が甫ノ渡犀を切つていないことから明らかである。

清水目層形成期 本形成期に入ると，西部山地の隆起は一段と激しくなり，父隆起も， 全面的に应大していつた。この際，矢張り白石集塊岩が隆起の主役を演じ，市ノ渡層形成期 より一段々その規模を搪大している。しかしながら，市ノ渡層形成期と本形成期における

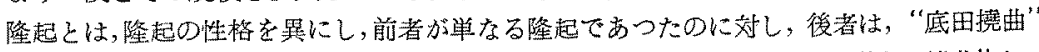
にみられるような，衝上性造棈力が働いたことが特徽である。すなわち “底田攃曲”は， 鎮西清高 (1958) が北上山地北端部地域で指摘している“辰ノ口撓曲”と一連の㩑曲運勤々 みられる。その運動形態は，東から西へと東西方向の力が働き，西方山珽がつき上るように 


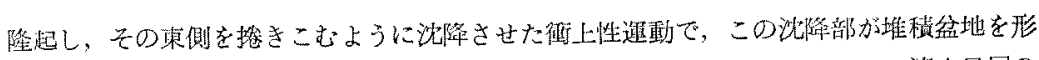

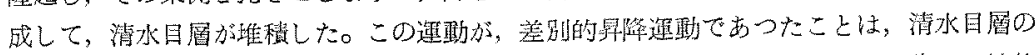
層厚の夜化からうかがわれ，この際隆起の中心部は白石集塊皆であつだこの㓌起の性格

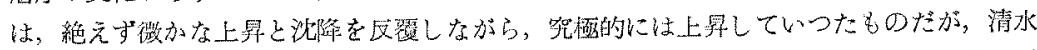

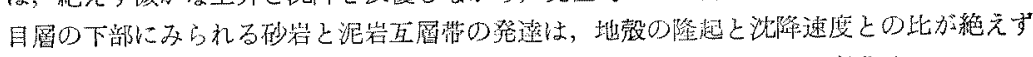

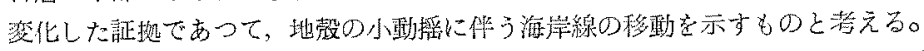

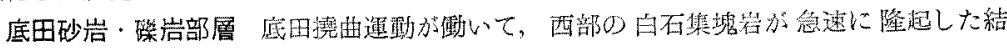

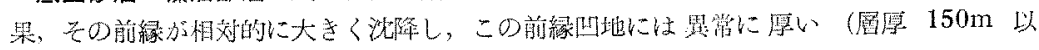

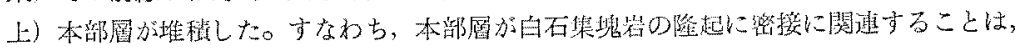

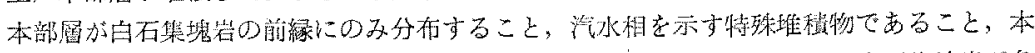

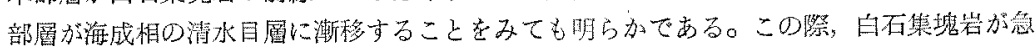

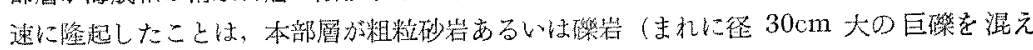

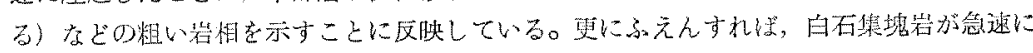
隆起寸ることによつて，漫触がさかんに行われ，この漫玲應物が河川により連搬されて，

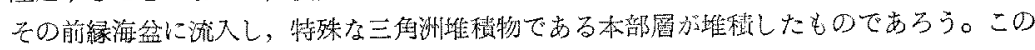

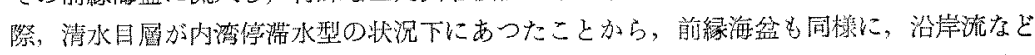

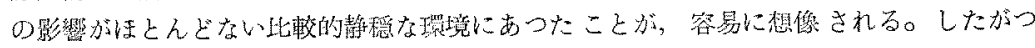

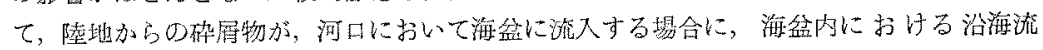

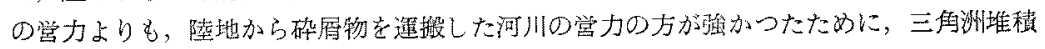
物が容易に堆程したものであろう。この三角洲堆積物が形成される当時社, 市了源層形成

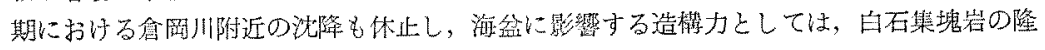

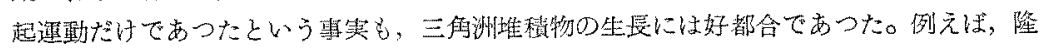

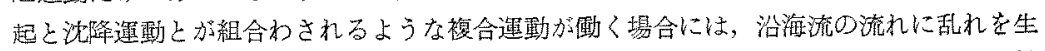
することが洘えられ，堆皘条件が椱雑になるので，簡単に三角洲堆積物が生成したとは推

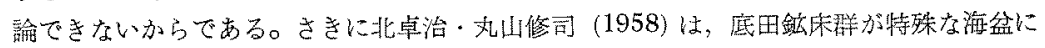
堆積したことに注目し，これを七海盆と呼んだが，等者は，低田砂岩䃯岩部㬝を堆積し た海盆を，あらためて“古七戸海盆”(Palaeo-Shichinohe Basin) と呼ふことにする。

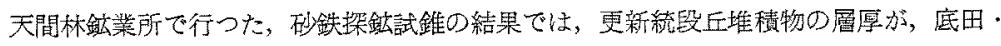
古和備附近では $50 \mathrm{~m}$ 以上と，ほかの地区よりも買常に愿いこと判つた（第 5 因）。この

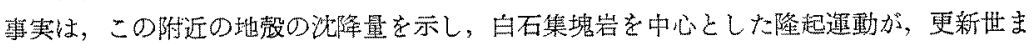
で継続した証示である。また，天間林村白石西方の白石集塊岩地域が，㘿近の水準測量の 結果晾，年々わずかながら上昇していることが確められており，白石集塊岩は現在でも な新甤起しつつある。

\section{C. 砂鉄鉱床の堆積および変形過程の解折}

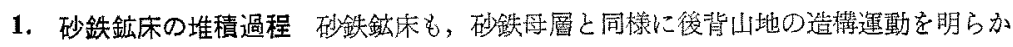

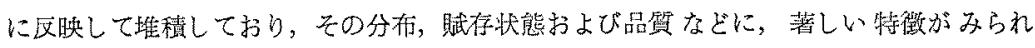
る。次にここような砂鉄の堆皘過程を鉣床别に砸述する。

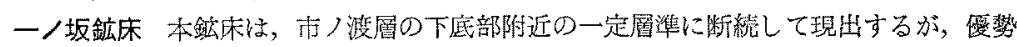

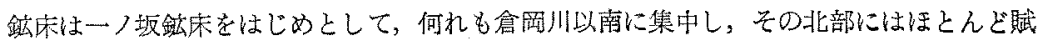




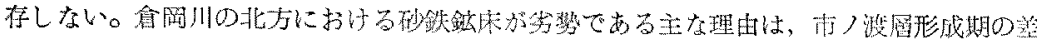

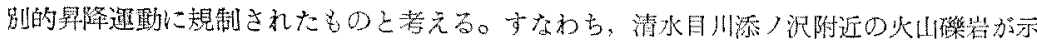
唆するごとく，一部に激しく隆起した地区もあつたが，Zの他の大部分の地区では，白石

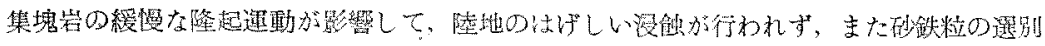

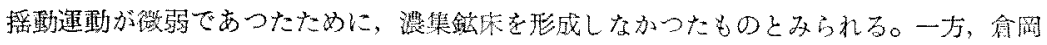

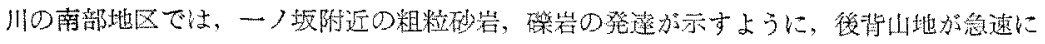

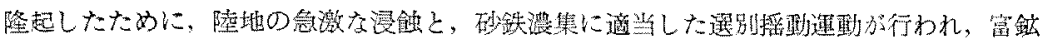

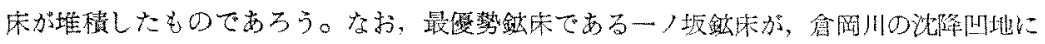

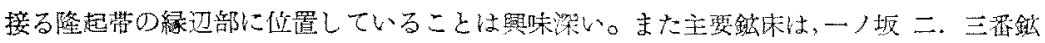

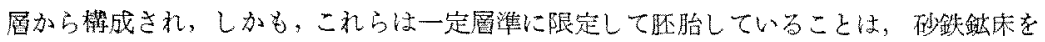

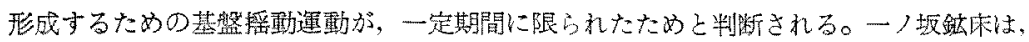

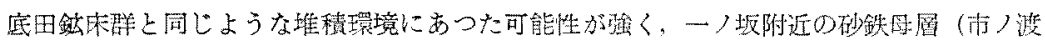

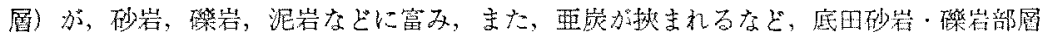

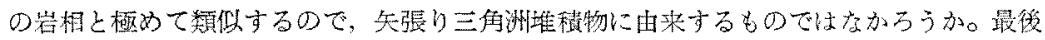

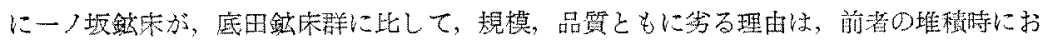

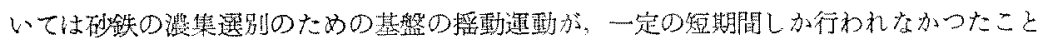

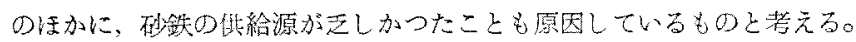

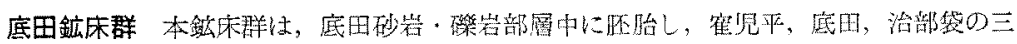

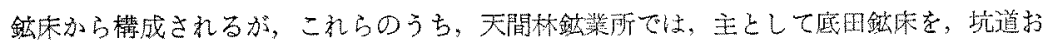
よび試錐により開発している。

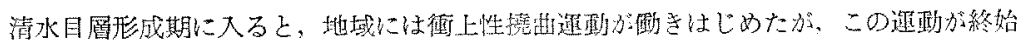

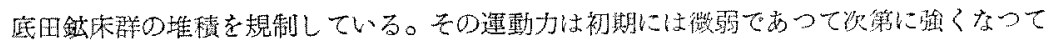

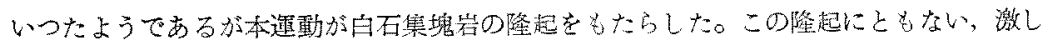

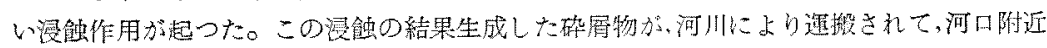

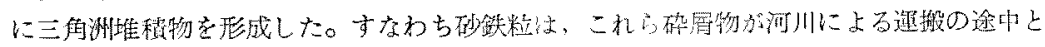

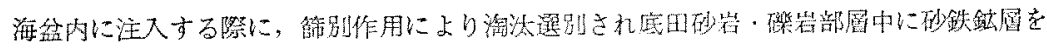

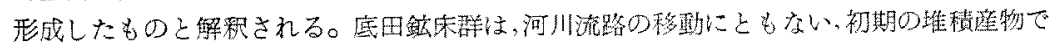

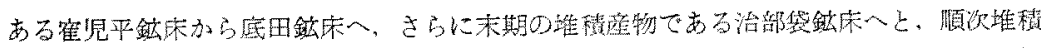

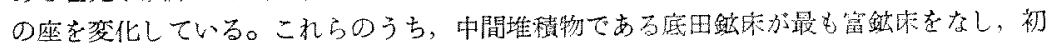

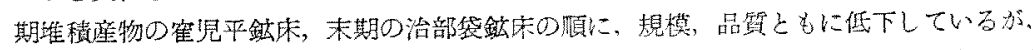

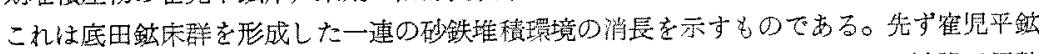

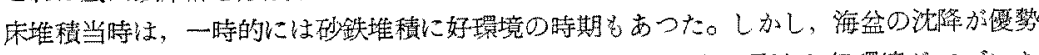

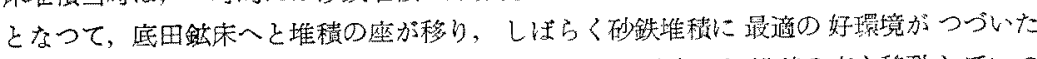

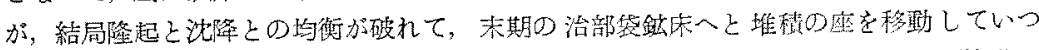
た。この治部袋銥床堆楥当時は，白石集塊岩の隆起が激しくなるにつれて，古七户海盆の 湥降が著しくなつた結果，矽鉄堆積に不良珼境をもたらし，その鉱床規模は小さくなり， 砂鉄の品算もまた低下したものであろう。

底田鉱床は，白石集塊岩の隆起の中心を逸れだ，その南末端部附近の前緣部に賦存して

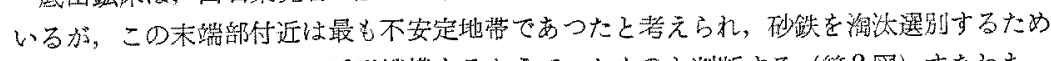

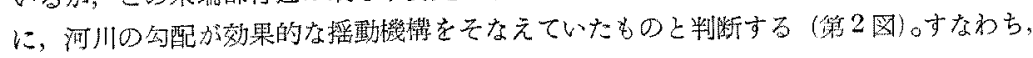




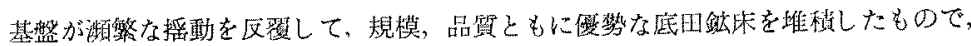

籹の砂鉄鉝層が，北部と南部にわかれて存在するが，巨視的にみれば，これらは同一堆程

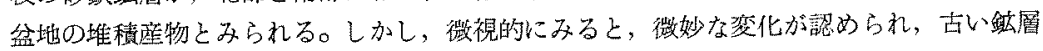

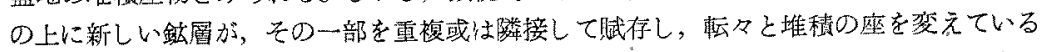
が，二れらは河口の小移動による転移と，河川の水流の变化に伴う現象と思われる。また，

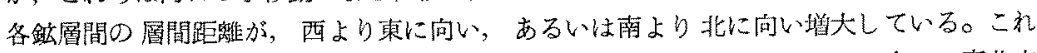
は，東西方向では，東方におむむくにつれて，沈降量の大きい海盆の中心に向い，南北方 向では，北方におもむくにしたがい，白石集塊岩の隆起の中心に近づくから，その前緑盆 地の沈降量が大きくなるので，夫マ層間距離の增大となつて区映したものであろう。この 事实は，また海盆内の水流の方向が南西より北東方向へと流れていたことを示昖してい

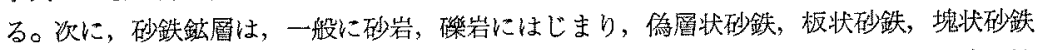
の順序にかさなり，凝灰硰，泥岩（しばしば炭化流木を舍を垔炭を伴う）に終る一連の輸

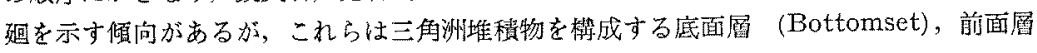
(Foreset) あるいは頂上層（Topset）に绫当する証拠が多い。

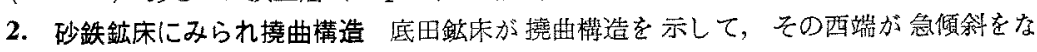
し，東部の地下で緩傾斜をなすことは，前述したとおりである。この急傾斜鈗層は，砂鉄

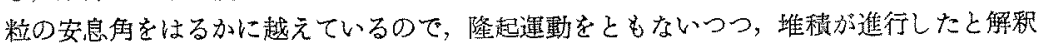

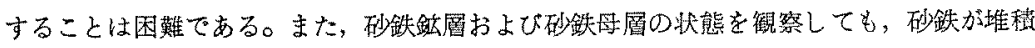
固結した後に褔曲運動が行われて，撓曲構造を形成したものと考えるには無理がある。こ のようにみてくると，この撓曲桖造は，砂鉄鉣層が堆積して，未だ可塑性の状態にあつた 当時に働いた，底田撓曲運動に起因すると考えるのが㚣当である。この場合，白石集塊岩 の隆起が拡大すれば，汀線であつた隆起と沈降との境界附近にあたる底田砂岩・沙岩部層 の西端部が，最も不安定であり，隆起の影響を受けやすいことが当然考えられる。したが

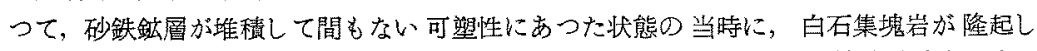

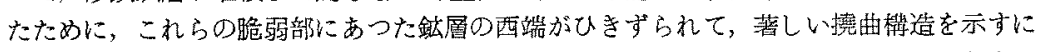

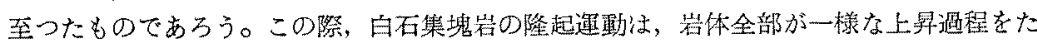
どつたものではなく，その途中では局部的に上畀力が異つていたために，部分的に小隆起 あるいは小沈降を繰返しながら，隆起していつたに違いない。たとえば、第4 層潐にある北 部の第 2 鉣尿と南部の第 8 銃層にみるように，同一層潐にあつても，鉙層の撓曲形態が夫

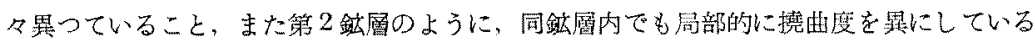
ことなどは部分的な小隆起があつたことを物語つている。なおこの攃曲䄻造の極端な 場合は，第 2 銥層のように，砂鉄母層および铈層が逆転している(第 5 图)。これは，隆

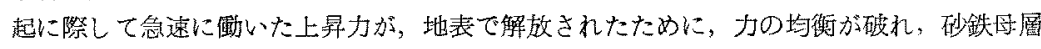

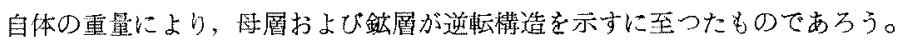

\section{D. 砂鉄の堆積環境に関する一考察}

砂鉄の堆積環境およぴその機構については未だ定説がないが，現世の海岸砂鉄は一般に 潮干带に形成された汀線打上型と考えられ扔り，海底に濃集している砂鉄粒が，沿岸の気 象, 風波の力向上強さおよび周期，沿海流，海岸ならびに海底地形などに支配され，汀線 附近に打上げられだのとされている。地質時代の砂鉄も，現㨁の海岸砂鉄とその應状が 
似ているので、これと類似の環境で堆皘したものと推定しているが，地筫時代の砂鉄には 炭筫物を随伴する点で，特殊な堆積環境にあつたのではないかと注目している者（服部， 1960) もある。筆者は，本地域をはじめとして，三，四の山砂鉄を梭討した結果，河口 堆程物起源を支持する，次の諸現象が諗められることに気がついた。

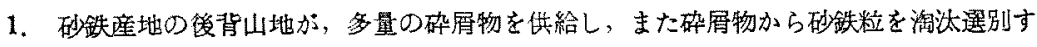
るのに，摇動運動が行われやすい基盤の隆起地滞に位置していること。…青森紫

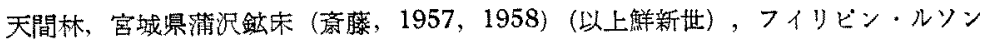
島北部 Dilalongan 地区（斎滕・村上，1963）(更新世)

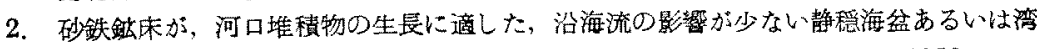

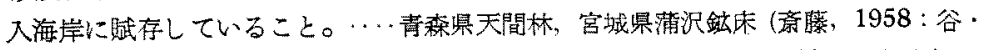

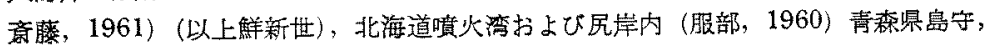
是川地区（北・五十闰，1956）（以上更新世）

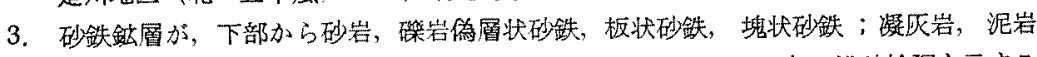
(しばしば炭貿物をはさむ)に終る三角洲烓䅪物を暗示する一連の堆積輪廻を示すこ

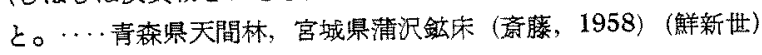

4. 砂鉄鉱床に有機質粘土又は炭筫物を随伴する例がみられること。…群再県中之条，

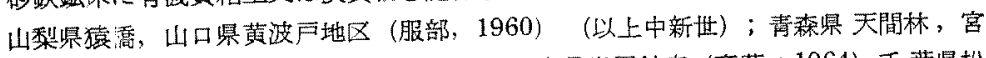

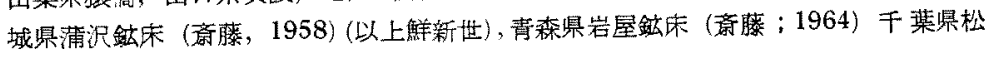
尾町附近（服部 1960）(以上更新世)

これらの諸事实は，地質時代の砂鉄が，一ノ坂および底田鉱床群と類似の堆積環境であ

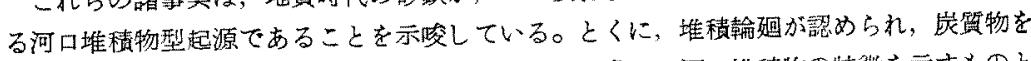
伴う点は、現世海岸砂鉄にはほとんどみられない現象で，河口堆榬物の特徴を示すものと 判断する。現进の主な汀線打上型海䛞砂鉄産地は，その背後に段丘砂鉄地带をひかえ，前 面には海底砂鉄を産する場合が多い。この海底砂鉄は，得背山地から由来した砂鉄粒と， 段丘砂鉄鉱床から分蜼逸脱した砂鉄粒と加混合存在しているものと思われるので，現世汀 線打上型砂鉄と河口堆栍物型の段丘砂鉄とは，本質的にその堆栍環境を買にする場合が多 いのであるまいか。青森暴下北半島の岩屋鉱床およびこの附近の現世海岸砂鉄，野牛沼 の湖成砂鉄（斎藤，1964）あるいは各地の海底砂鉄には，河口，小さい沢の入口部などに 鉣床か賦存し，またこれらを中心として潠集部を形成する例が認められ，また北海道北 乘津，千葉累飯岡蛇園（服部 1960）附近の現世砂鉄には有機質粘土を随伴することが報 告されているが，これらは，現世砂鉄にも河口㒕櫝物型鉙床の疗在を示唆している。要す るに砂鉄鉣床の堆栍環境には，汀線打上型と河口堆積物型との二種の型式があり，地資時

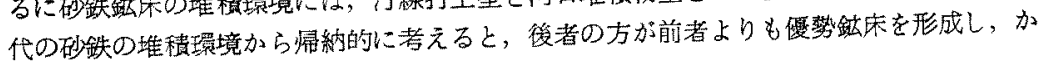
つ一般的な堆積環境ではないたろうか。

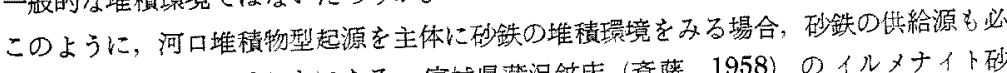

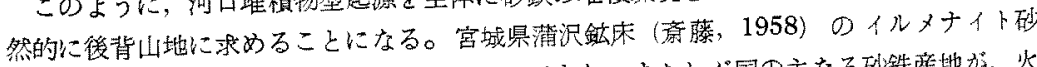
が，直く後背地から供給されたことは明らかであり，またかが国の主子る秒制赝地が，火 山地带の前面地域またはその附近に位置し，砂鉄の供給源が火山精成物にあることを喑示 しているがこれらは砂鉄が後背地が占由来したことを例証するものと考兄る。

いずれにしても，砂鉄の琟積環境およびその機棰にいては，複雑な問題を包含してお 
り，今得さらに詳しく檢討した上，别途に報告することにしたい。

\section{4. 結 票}

1. 本地域における砥鉄鉣床の堆榬は，中新茾に属する前小坪川層形成期，小玶川層形成 期をとおして活勤した，北西〜南東方向の上曰断層の造棈運勒に造因を発している。その 連動は，断層の南西側が隆起し，その北東側が傾動沈降したもので，この沈祭の中心部お よび本断層きわには白石集塊岩が堆稜した。

2. 白石集塊岩は, 水平方向一の岩変相化が著しく, 小呯川啳の砂岩, 泥岩, 凝死岩など に移化している。白石集塊岩の喷出機樓は，噴出と沈降を繰返しながら，厚層をなして堆 栍したものであつて，その噴出孔は東西性裂力が関係した。

3、市ノ渡層形成期には，その西部山地汃沈降から隆起に転化し，隆起带の前縁盆地の摤 小な範囲に市ノ渡層が堆積した。この隆起は差别的界降運動の性格を带びていたので，市 ノ渡の绝愿層は地区ごとに変化している。

4. 清水目層形成期には，東加ら西方向の“底田撓曲连動”加働き，白石集塊岩を中心と した西部山地が隆起し，東部が沈降した。清水目層および底田砂岩・䃯岩部層は，この運 動に規制されてその前縁海盆に堆積したもので，白石集塊岩は，更新世を経て現在まで， なお隆起を糘けている。

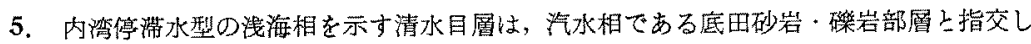
ている。底田砂岩・砂岩部層は, 白石集塊岩の隆起に闒保して形成された三角洲琟積物で あつて，その南前粶部の古七戸海盆に堆積し，特異な分布と岩䐝を示している。

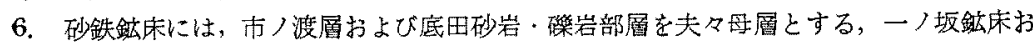
よび底田鉙床群がある。

7.一ノ坂鉣床は, 規模が小さく, 品質も劣勢であつて, 三角洲堆積物中に濃勧した砂鉄 とみられるが，これを支持する積極的な資料にとはしく，更に検討を要する。

8. 底田鎕床群は，白石集塊岩の隆起運野と，密接に関係して堆稓している。すなわち， 白石集塊岩の隆起に伴い，盛んに椤蝕が行われ砾局物が生成した。河川により運ばれたこ

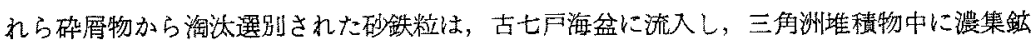
床を形成した。この際基盤の摇動運動に伴い 河川が移動したので, 点々と堆積の座が変 つた結果，底田銥床群の寉睍平，底田，治部监鉣床が堆積したが、これらのう方，底田銥

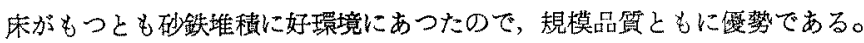

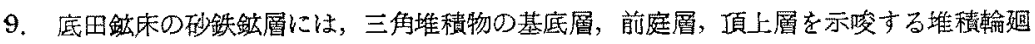
がみられるようである。

10. 底田鉱床が示す撓曲構造は，“底田撓曲”運動にともなう白石集塊岩の隆起の産物で ある。すなわち，砂鉄鋝層が堆積して間吕ない，未だ可塑性の状態にあつた当時に，白石 集塊岩が晸起し，隆起と沈降の境界に位置していた鉸床西端部が，局所的に隆起に引ずら れて嵒曲したものである。

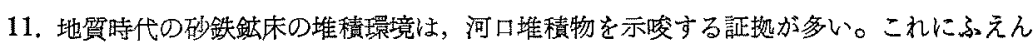
して，現世砂鉄には，汀線打上型のほかに河口堆栍物型矽鉄鍍床が存在することが予想 される。 


\section{引用文献}

鎮西清高 (1958)，北上山地北端部鮮新統の層序，地筫雑，64,526～536.

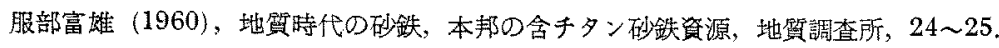
岩井渟一 (1963)，青㷊地貿图，青森罢

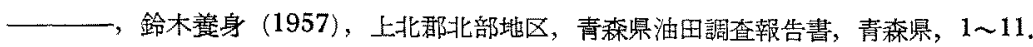
北 卓治, 五十嵐陖雄 (1956), 青森罢八戸地区, 未利用鉄資源 2,115 .

一一，丸山修司（1958），青森爆東部北陵地区，未和用鉄資源， 5,48～54.

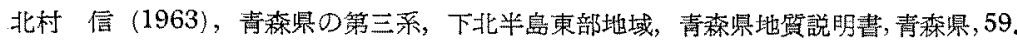
中川久夫 (1963)，青森䒬の第四采，青森罧地質説明書，青森喂，7.

小川泰司，斎藤洋㢁 (1958)，天間林鉝山地質鉉床精查，末利用鉄資源 5,68～69.

大木 恒, 牧干代太朗, 紊藤洋彦, 冨村裕之, 飯塚 浩 (1955), 天满銷山北部地域地貿

鉉床概查，未利用鉄資源 2,55 57。

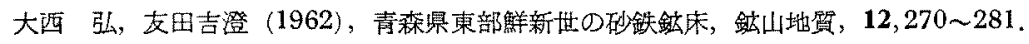

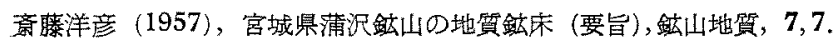

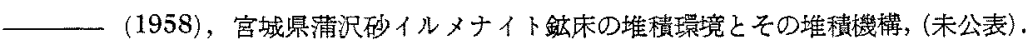

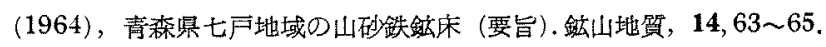

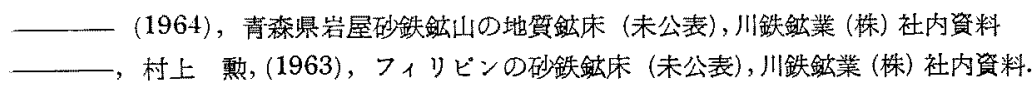

一, 冨村裕之, 柿沼翰次 $(1956)$, 天満鉣山北部地域地質鉱床精查, 未利用铁資源 $3,55 \sim 57$.

柴陭達夫，蓄木 小松直幹，大森隆一郎，藤田至則 (1958), 青森罢下北半島南部の 地質と地下水（藤本教授還歷記念論文集）.

谷 正己, 斎藤洋产 (1961), 宮城目蒲沢鉣山周辺地域の含チタン砂鉄鉣床, 地調月報,

$12,207 \sim 220$.

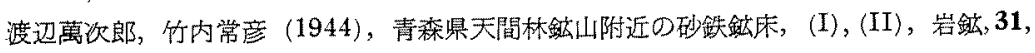

$177 \sim 188,197 \sim 206$. 